\title{
INFLUENCE OF COMPOSITIONAL MODIFICATIONS ON THERMAL STABILITY OF ALLOY 718.
}

\author{
E. Andrieu, N. Wang, R. Molins and A. Pineau \\ Ecole Nationale Supérieure des Mines de Paris \\ Centre des Matériaux P.M. Fourt \\ BP. 87, 91003 Evry Cedex 03 \\ URA CNRS 866
}

\begin{abstract}
Conventional Alloy 718 is compared to a modified alloy $(976 \mathrm{M})$ heat treated either with the usual heat treatment applied to Alloy 718 or with a specific heat treatment giving rise to the compact morphology microstructure.

This comparison is made on the basis of hardness measurements and microstructural modifications resulting from long term aging (10000 hours) applied at three temperatures $\left(650^{\circ} \mathrm{C}-700^{\circ} \mathrm{C}-750^{\circ} \mathrm{C}\right)$. It is shown that wathever the initial heat treatment is, the modified alloy has a better thermal stability than Alloy 718. A significant improvement is found at $700^{\circ} \mathrm{C}$ and $750^{\circ} \mathrm{C}$. Precipitate size and morphological evolution as well as volume fraction of delta phase has been measured as function of aging conditions. Tensile tests have been performed at temperatures ranging from room temperature to $750^{\circ} \mathrm{C}$. The results show that the tensile properties of the modified alloy are better than those of Alloy 718 .
\end{abstract}

\section{Introduction}

Alloy 718 is currently used as a disc material in gas turbine jet engines. The number of structural applications would undoubtly be increased if one could succeed in improving the high temperature fatigue crack growth resistance and the thermal stability of this material. The work reported in this paper is concerned with the latter objective.

After solution treatment at temperature $\left(\leq 1000^{\circ} \mathrm{C}\right)$ and a conventional aging treatment $\left(720^{\circ} \mathrm{C}\right.$ $\left.8 \mathrm{~h}-\mathrm{AC} .50^{\circ} \mathrm{C} / \mathrm{h}-620^{\circ} \mathrm{C}-8 \mathrm{~h}\right)$ this alloy is strengthened by two types of precipitates, $\gamma^{\prime}\left(\mathrm{Ni}_{3}(\mathrm{Al}\right.$, $\mathrm{Ti})$ ) and $\gamma^{\prime \prime}(\mathrm{Ni} 3 \mathrm{Nb})$. It may also contain the stable phase $\delta\left(\mathrm{Ni}_{3} \mathrm{Nb}\right)$ precipitated along the grain boundaries.

The TTT diagrams published by Brooks and Bridge [1] and by Radavich [2] show that the sequence of precipitation depends on the solution heat treatment. The former authors indicate that $\gamma^{\prime \prime}$ precipitates are formed before $\gamma^{\prime}$ during the isothermal treatment while Radavich has proposed the inverse sequence. From these different behaviours one can conclude that it is difficult to control the precipitation of $\gamma$ phases without a modification of the chemical

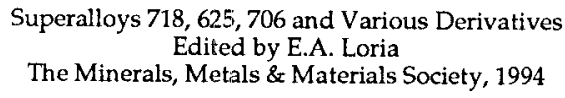


composition of the alloy. This control is critical when it is intended to develop associated precipitation of both phases to produce the so-called compact morphology (3).

Due to the crystallographic specificity of each phase, it is interesting to promote the nucleation of one phase before the other one. In the early seventies Cozar and Pineau [3] showed that $\gamma$ nucleation was promoted by increasing the $\mathrm{Al}$ and $\mathrm{Ti}$ content of the alloy.

Several compositions derived from alloy 718 were then investigated. It was shown that it was possible to find heat treatments giving rise to an associated precipitation of $\gamma^{\prime}-\gamma^{\prime \prime}$ called compact morphology. The formation of this morphology can be described as a two steps precipitation process The first step corresponds to the nucleation and growth of cubic shaped $\gamma^{\prime}$ particles while the second one is associated with the precipitation of $\gamma^{\prime \prime}$ on the side faces of the $\gamma^{\prime}$ cubes. This microstructure has proved to exhibit excellent thermal stability since it was shown that the precipitate size did not change after aging treatments of several hundred of hours at $750^{\circ} \mathrm{C}$. The conditions required to obtain the compact morphology are summarized in fig. 1a and $1 \mathrm{~b}$. After a solution treatment, the $\left(\theta_{1}, t_{1}\right)$ thermal treatment must ensure that only $\gamma$ phase precipitates and grows up to a $20 \mathrm{~nm}$ diameter. The cooling rate $V_{R}$ and $\left(\theta_{2}, t_{2}\right)$ heat treatment has to achieve the compact morphology formation by covering the initial $\gamma^{\prime}$ particles with a layer of $\gamma^{\prime \prime}$ phase along the six faces of the $\gamma^{\prime}$ phase.

The chemical compositions which lead after an optimised heat treatment to this associated precipitation must be included within the MNOP band defined in diagram shown in Fig. $1 \mathrm{~b}$ where $\mathrm{S}=\mathrm{Ti}+\mathrm{Al}+\mathrm{Nb}(\mathrm{At} \%)$ and $\mathrm{R}=\mathrm{Ti}+\mathrm{Al} / \mathrm{Nb}$.

The aim of the present study is to compare the high temperature thermal stability of conventional Alloy 718 with a modified alloy whose chemical composition may lead to the compact morphology. The comparison is made on the basis of hardness measurements and microstructural modifications that occur during long term aging (up to $10^{4} \mathrm{~h}$ ) at $650^{\circ}, 700^{\circ} \mathrm{C}$ and $750^{\circ} \mathrm{C}$.

\section{Materials and experimental procedures}

\section{Materials composition - heat treatment}

Two heats were used, namely Alloy 975 and Alloy 976. The chemical compositions of both materials are presented in table 1 and the compositions of each alloy are plotted in the S-R. Diagram (fig.1b). Alloy 975 is equivalent to conventional 718 whereas a compact morphology is expected for Alloy 976. IMPHY S.A. has chosen the powder metallurgy route to prepare both materials.

Table 1 - Chemical composition of the alloys (At \%).

\begin{tabular}{cccccccc|ccc}
\hline HEAT & $\mathrm{Ni}$ & $\mathrm{Cr}$ & $\mathrm{Mo}$ & $\mathrm{Fe}$ & $\mathrm{Al}$ & $\mathrm{Ti}$ & $\mathrm{Nb}$ & $\mathrm{S}$ & $\mathrm{R}$ & $\mathrm{Al} / \mathrm{Ti}$ \\
\hline 975 & bal & 20.24 & 1.81 & 19.63 & 1.17 & 1.24 & 3.39 & 5.8 & 0.71 & 0.94 \\
976 & bal & 19.73 & 1.82 & 19.52 & 2.26 & 1.48 & 3.13 & 6.87 & 1.20 & 1.53 \\
\hline
\end{tabular}

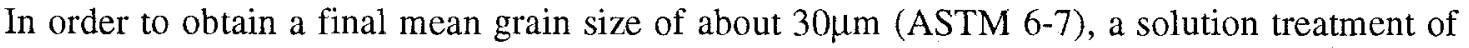
$30 \mathrm{mn}$ at $1025^{\circ} \mathrm{C}$ was given. Then the heat treatment giving rise to the compact morphology was studied. Several combinations $\left(\theta_{1}, t_{1}\right)-V_{R^{-}}\left(\theta_{2}, t_{2}\right)$ were explored. They are summarized in table 2 with the corresponding hardness values. 


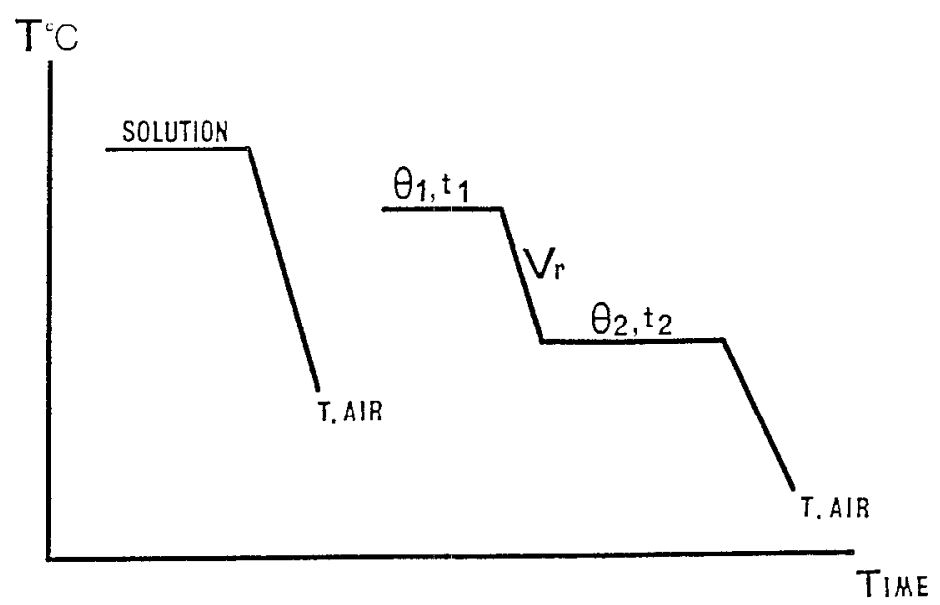

Figure 1a - Diagram of the different heat treatment sequences necessary to obtain the compact morphology.

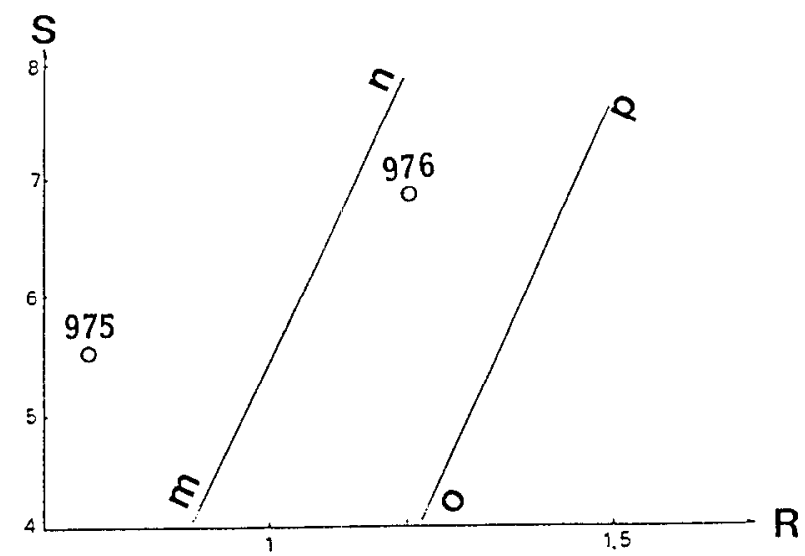

Figure $1 \mathrm{~b}-\mathrm{S}-\mathrm{R}$ diagram defined by Cozar and Pineau $(3,4) . \mathrm{S}=\mathrm{Ti}+\mathrm{Al}+\mathrm{Nb} ; \mathrm{R}=(\mathrm{Ti}+\mathrm{Al}) / \mathrm{Nb}$ (at \%) 
Table 2 - The different $\left(\theta_{1}, t_{1}\right)-v_{R}-\left(\theta_{2}, t_{2}\right)$ conditions explored to obtain the compact morphology.

\begin{tabular}{ccc}
\hline$\theta_{1}, \mathrm{t}_{1}$ & $\mathrm{v}_{\mathrm{R}} \theta_{2}, \mathrm{t}_{2}$ & (HV20) Hardness \\
\hline $850^{\circ} \mathrm{C} / 30 \mathrm{~min}$ & $50^{\circ} \mathrm{C} / \mathrm{h}-650^{\circ} \mathrm{C} / 16 \mathrm{~h} \mathrm{A.C}$ & 430 \\
$850^{\circ} \mathrm{C} / 30 \mathrm{~min}$ & $10^{\circ} \mathrm{C} / \mathrm{h}-650^{\circ} \mathrm{C} / 16 \mathrm{~h} \mathrm{A.C}$ & 424 \\
$850^{\circ} \mathrm{C} / 30 \mathrm{~min}$ & $100^{\circ} \mathrm{C} / \mathrm{h}-650^{\circ} \mathrm{C} / 16 \mathrm{~h} \mathrm{A.C}$ & 450 \\
$850^{\circ} \mathrm{C} / 30 \mathrm{~min}$ & $200^{\circ} \mathrm{C} / \mathrm{h}-650^{\circ} \mathrm{C} / 16 \mathrm{~h} \mathrm{A.C}$ & 454 \\
$850^{\circ} \mathrm{C} / 30 \mathrm{~min}$ & $100^{\circ} \mathrm{C} / \mathrm{h}-650^{\circ} \mathrm{C} / 16 \mathrm{~h}+700^{\circ} \mathrm{C} / 24 \mathrm{~h} \mathrm{A.C}$ & 444 \\
$850^{\circ} \mathrm{C} / 30 \mathrm{~min}$ & $300^{\circ} \mathrm{C} / \mathrm{h}-750^{\circ} \mathrm{C}-50^{\circ} \mathrm{C} / \mathrm{h}-650^{\circ} \mathrm{C} / 16 \mathrm{~h} \mathrm{A.C}$ & 457 \\
\hline
\end{tabular}

T.E.M. was used to find among the different combinations the one which generates the best microstructure. The last one given in Table 2 was selected after several attempts. An example of the corresponding microstructure called $976 \mathrm{M}$ is presented on fig.2. It appears from this dark field TEM micrograph that $\gamma^{\prime}$ particules are surrounded by $\gamma^{\prime \prime}$ platelets so that a compact morphology is achieved. Nevertheless, one can notice that some $\gamma^{\prime \prime}$ platelets are longer than the associated $\gamma^{\prime}$ particles.

Conventional heat treatments were given on alloy 975 and 976 so that three microstructures were selected for this study, ie Alloy 975, Alloy and Alloy 976M. The corresponding heat treatments are listed in Table 3.

Table 3 - Heat treatments selected in the present study.

\begin{tabular}{lll}
\hline Alliage 975 & $1025^{\circ} \mathrm{C} / 30 \mathrm{~min}$ A.C $+720^{\circ} \mathrm{C} / 8 \mathrm{~h}$ & $750-\left(50^{\circ} \mathrm{C} / \mathrm{h}\right) \rightarrow 620^{\circ} \mathrm{C} / 8 \mathrm{~h} \mathrm{A.C}$ \\
Alliage 976 & $1025^{\circ} \mathrm{C} / 30 \mathrm{~min}$ A.C $+720^{\circ} \mathrm{C} / 8 \mathrm{~h}$ & $750-\left(50^{\circ} \mathrm{C} / \mathrm{h}\right) \rightarrow 620^{\circ} \mathrm{C} / 8 \mathrm{~h} \mathrm{A.C}$ \\
Alliage $976 \mathrm{M}$ & $1025^{\circ} \mathrm{C} / 30 \mathrm{~min}$ A.C $+850^{\circ} \mathrm{C} / 30 \mathrm{~min}$ & $300^{\circ} \mathrm{C} / \mathrm{h} \rightarrow 750^{\circ}-\mathrm{C} 50^{\circ} \mathrm{C} / \mathrm{h} \rightarrow 650^{\circ} \mathrm{C} / 16 \mathrm{~h}$ \\
\hline
\end{tabular}

Tensile properties.

Increasing the thermal stability of alloy 718 has a great potential if the mechanical properties of the new alloy remain acceptable. This is the reason why tensile tests were performed on the two Alloys $975,976 \mathrm{M}$ at different temperatures $\left(25^{\circ} \mathrm{C}-550^{\circ} \mathrm{C}-650^{\circ} \mathrm{C}-700^{\circ} \mathrm{C}-750^{\circ} \mathrm{C}\right)$. The results of these tests are reported in Table 4 . It is worth noting that the tensile mechanical properties of both alloys are quite satisfactory. The compact morphology microstructure exhibits a higher work-hardening rate up to a testing temperature of $700^{\circ} \mathrm{C}$. When the temperature is larger than $600^{\circ} \mathrm{C}$, the ductility decreases. This coincides with a change in fracture mode which transgranular at low temperature becomes intergranular above $600^{\circ} \mathrm{C}$. 


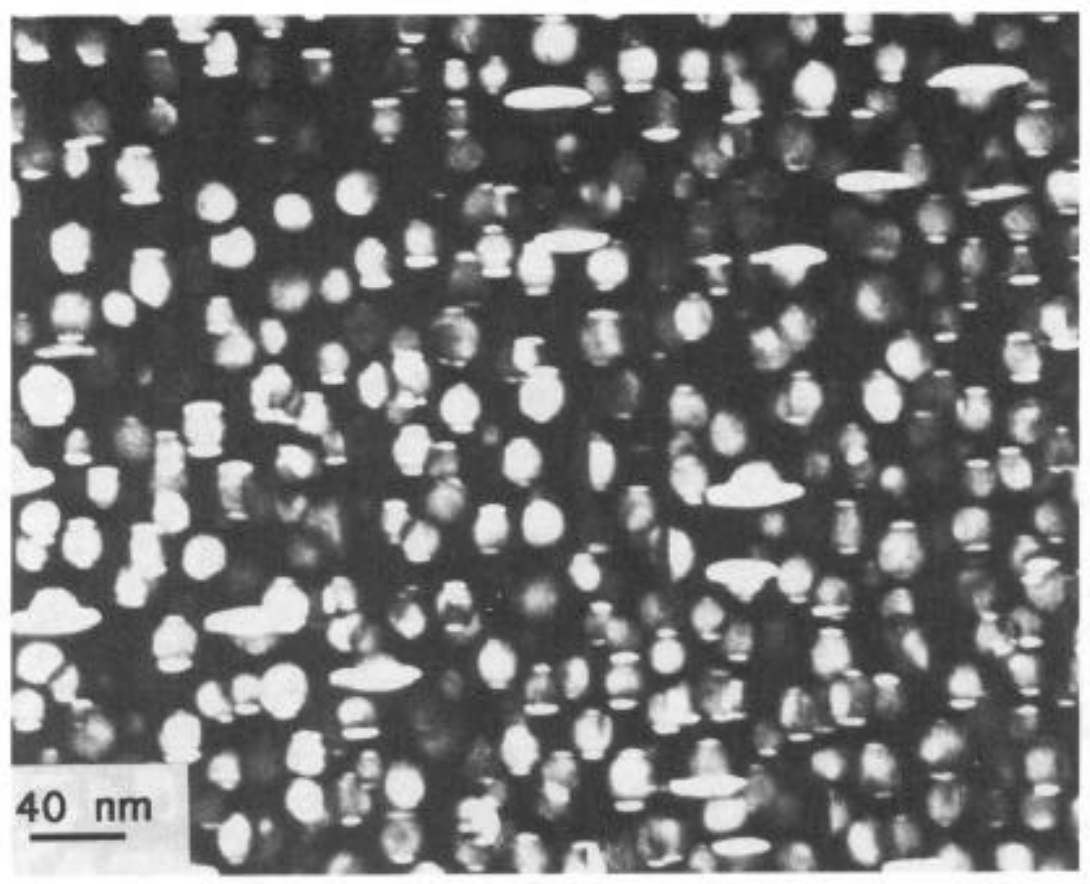

Figure 2 - Dark field TEM micrograph, showing the associated precipitation of $\gamma$ and $\gamma^{\prime \prime}$ phases.

Table 4 - Tensile properties.

\begin{tabular}{|c|c|c|c|c|c|}
\hline \multirow[t]{2}{*}{ MATERIALS } & \multicolumn{5}{|c|}{ Ultimate Tensile Strength (MPa) } \\
\hline & $25^{\circ} \mathrm{C}$ & $550^{\circ} \mathrm{C}$ & $650^{\circ} \mathrm{C}$ & $700^{\circ} \mathrm{C}$ & $750^{\circ} \mathrm{C}$ \\
\hline $976 \mathrm{M}$ & 1466 & 1323 & 1195 & 1061 & 877 \\
\hline \multirow[t]{3}{*}{975} & 1403 & 1195 & 1114 & 1024 & 799 \\
\hline & \multicolumn{5}{|c|}{ Yield Strength $(0.2 \%)(\mathrm{MPa})$} \\
\hline & $25^{\circ} \mathrm{C}$ & $550^{\circ} \mathrm{C}$ & $650^{\circ} \mathrm{C}$ & $700^{\circ} \mathrm{C}$ & $750^{\circ} \mathrm{C}$ \\
\hline $976 \mathrm{M}$ & 1146 & 1041 & 973 & 932 & 806 \\
\hline \multirow[t]{2}{*}{975} & 1234 & 1032 & 967 & 937 & 770 \\
\hline & \multicolumn{5}{|c|}{ Total Elongation $(\%)$} \\
\hline & $25^{\circ} \mathrm{C}$ & $550^{\circ} \mathrm{C}$ & $650^{\circ} \mathrm{C}$ & $700^{\circ} \mathrm{C}$ & $750^{\circ} \mathrm{C}$ \\
\hline $976 \mathrm{M}$ & 18.9 & 13.1 & 12.5 & 8.7 & 6.3 \\
\hline \multirow[t]{3}{*}{975} & 27.1 & 10.9 & 14.5 & 9.1 & 4.9 \\
\hline & \multicolumn{5}{|c|}{ Reduction in Area (\%) } \\
\hline & $25^{\circ} \mathrm{C}$ & $550^{\circ} \mathrm{C}$ & $650^{\circ} \mathrm{C}$ & $700^{\circ} \mathrm{C}$ & $750^{\circ} \mathrm{C}$ \\
\hline $976 \mathrm{M}$ & 31.7 & 21.4 & 12.3 & 11.6 & 9.1 \\
\hline 975 & 42.7 & 34.9 & 17.8 & 13.8 & 6.6 \\
\hline
\end{tabular}




\section{$\underline{\text { Results and discussion }}$}

\section{Hardness variation during aging}

The variations of hardness with aging times at three temperatures $\left(650^{\circ} \mathrm{C}, 700^{\circ} \mathrm{C}, 750^{\circ} \mathrm{C}\right)$ are shown on Fig.3.

At $650^{\circ} \mathrm{C}$, Alloy 975 starts to be overaged after a couple of thousands of hours while Alloy $976 \mathrm{M}$ remains stable. The hardness of Alloy 976 increases during the first thousand of hours and then remains stable up to 10000 hours. The initial heat treatment given to Alloy 976 is not sufficient to complete the precipitation of $\gamma^{\prime}, \gamma^{\prime \prime}$ while Alloy $976 \mathrm{M}$ which has the compact morphology is stable all along the aging treatment. At $700^{\circ} \mathrm{C}$, the chemical composition of Alloy 975 is unable to maintain the hardness constant after 200 hours while alloys 976 and $976 \mathrm{M}$ remain stable up to 5000 hours. However, after this delay the hardness of the two latter alloys decreases rapidly. At $750^{\circ} \mathrm{C}$, the hardness of the three alloys decreases but it remains still higher for Alloys 976 and $976 \mathrm{M}$.

These results indicate that it is possible to reduce the overaging sensitivity of Alloy 718 by minor modifications of the chemical composition. With such microstructural modifications one can expect an increase of $25^{\circ} \mathrm{C}$ of the temperature limit of use for long term exposure.

\section{Microstructural modifications}

The microstructural modifications were studied qualitatively by using TEM and SEM techniques. The initial microstructure of alloys $975,976,976 \mathrm{M}$ was observed.

In alloy 975 , the microstructure obtained after the initial heat treatment corresponds to an independent precipitation of $\gamma^{\prime}$ and $\gamma^{\prime \prime}$ phases. The average size of the $\gamma^{\prime \prime}$ precipitates has been measured and found to be equal to $26 \mathrm{~nm}$. In this alloy, as in conventional 718 , the volume fraction of $\gamma^{\prime \prime}$ is larger than that of $\gamma^{\prime}$.

Alloy 976 has received the same heat treatment as Alloy 975 (Table 3) but as chemical compositions are slightly different, the initial microstructures are also different $: \gamma^{\prime \prime}$ precipitates are smaller $(10 \mathrm{~nm})$ than in the Alloy 975 and the volume fraction of $\gamma^{\prime \prime}$ particles is larger.

Microstructures of alloys aged up to 10000 hours at $650^{\circ} \mathrm{C}$ have been observed by SEM. They are shown in figure 4. In all cases, the precipitates grow or coarsen. A detailed study of this phenomenom is presented later on. The growth rate is higher in Alloy 975. Moreover, in each microstructure $\delta$ phase precipitates along the grain boundaries and occasionally within the grains. It is worth noting that the precipitation of this phase is more important in Alloy 975 than in Alloys 976 and $976 \mathrm{M}$.

In figure 5 are presented SEM micrographs corresponding to a 5000 hours aging treatment at $700^{\circ} \mathrm{C}$. The size of $\gamma^{\prime}$ and $\gamma^{\prime \prime}$ precipitates are smaller in the two modified alloys than in Alloy 975. The compact morphology seems to have disappeared in Alloy 976M. An important precipitation is observed along the grain boundaries. These intergranular phases have been identified as $\delta$ phase and a Mo, $\mathrm{Cr}$ rich phase. This latter phase is suspected to be the $\alpha$-Cr phase mentioned by Radavich [2]. This intergranular precipitation is accompanied by the formation of a $\gamma^{\prime \prime}$ precipitate free zone close to the grain boundaries The phenomenom is very intense in Alloy 975. When aging time reaches 10000 hours at $700^{\circ} \mathrm{C}$, observations mentioned just above become more obvious. These microstructural modifications are shown in Fig. 6. At this stage, the precipitation of $\delta$ phase in Alloy 975 is so important that the $\gamma^{\prime \prime}$ particles have almost completely desappeared.

Finally, the microstructural evolutions occurring after a 10000 hours aging at $750^{\circ} \mathrm{C}$ are presented in Fig. 7. All the alloys behave similarly. The $\delta$ phase has fully replaced $\gamma^{\prime \prime}$ phase. 

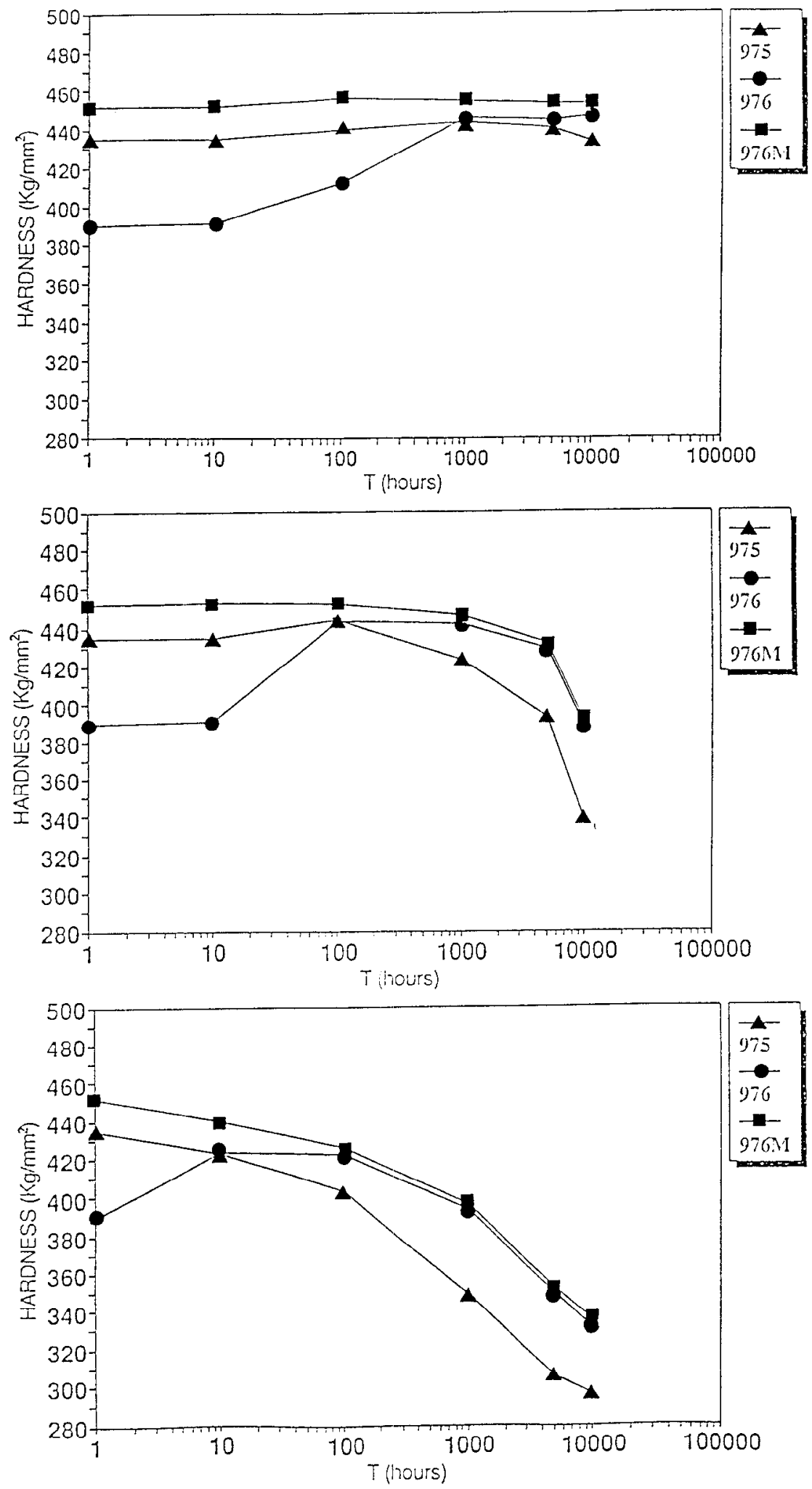

Figure 3 - Hardness (HV20) variation as a function of aging time for alloys 975, 976, 976M. $\mathrm{A}-650^{\circ} \mathrm{C}, \mathrm{B}-700^{\circ} \mathrm{C}, \mathrm{C}-750^{\circ} \mathrm{C}$. 

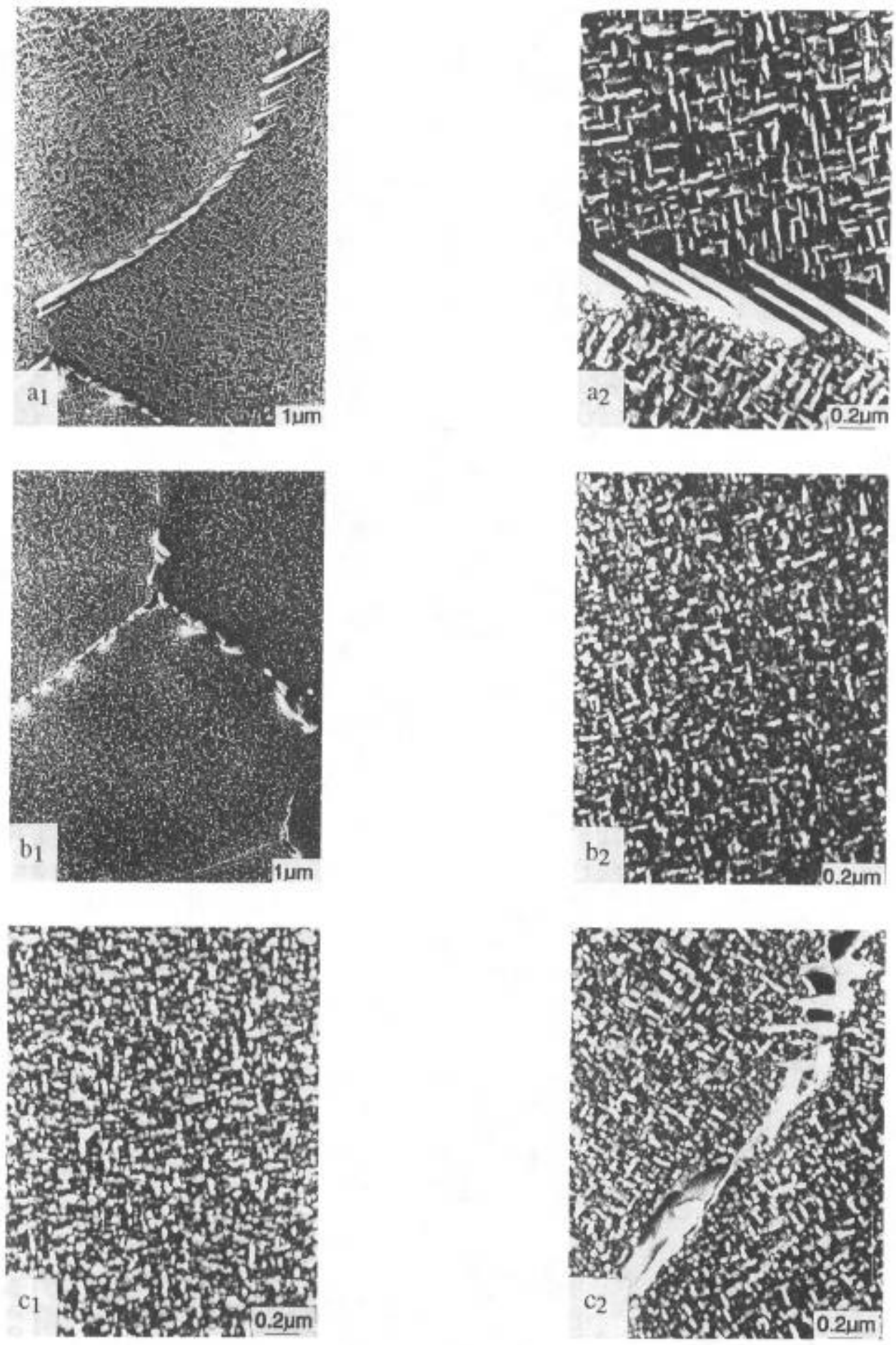

Figure 4 - SEM micrographs showing the microstructural evolutions after $10^{4}$ hours at $650^{\circ} \mathrm{C}$.

$$
\begin{aligned}
& \mathrm{a}_{1}, \mathrm{a}_{2} \rightarrow \text { Alloy } 975 \\
& \mathrm{~b}_{1}, \mathrm{~b}_{2} \rightarrow \text { Alloy } 976 \\
& \mathrm{c}_{1}, \mathrm{c}_{2} \rightarrow \text { Alloy } 976 \mathrm{M}
\end{aligned}
$$



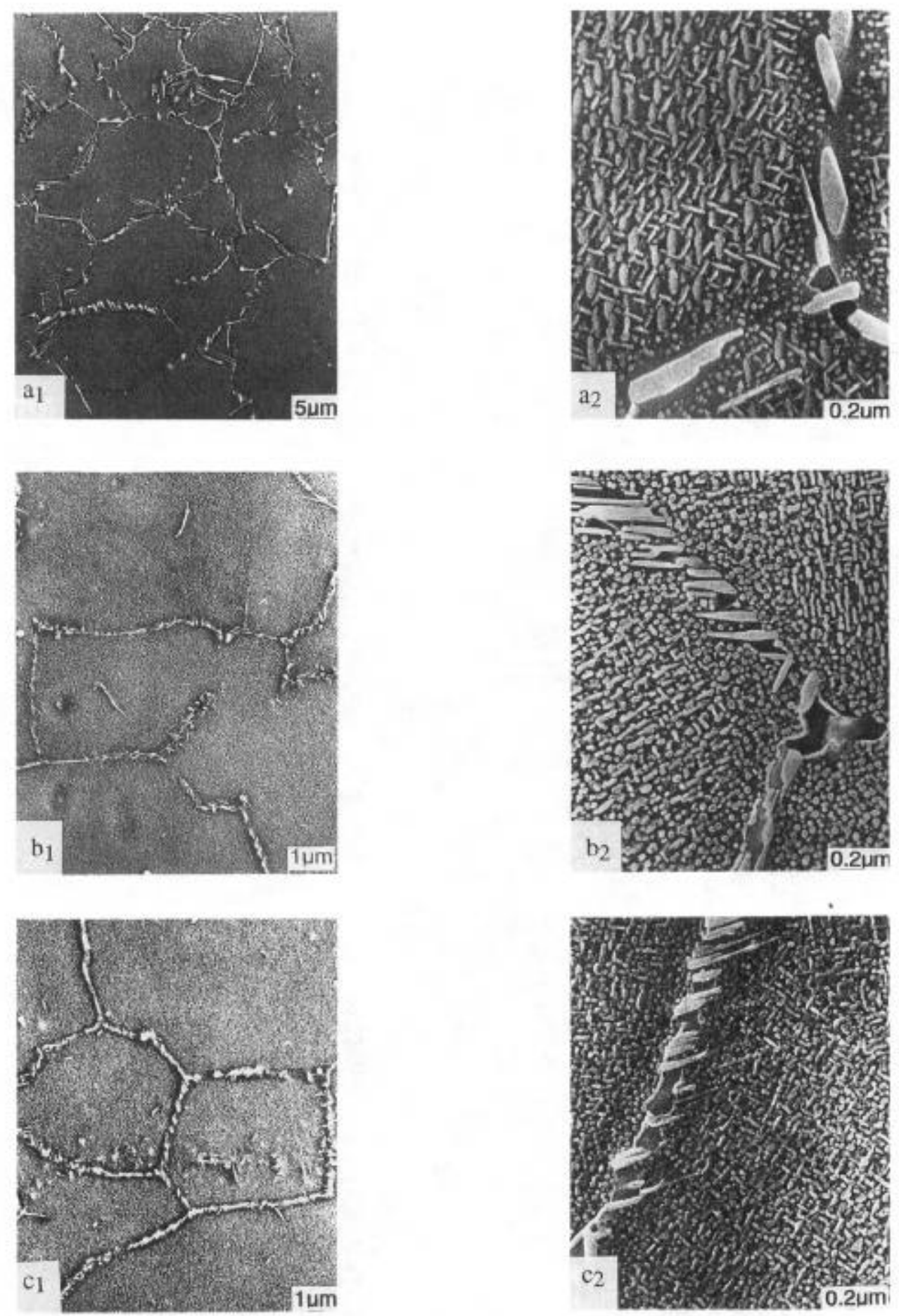

Figure 5 - SEM micrographs showing the microstructural evolutions after $5.10^{3}$ hours at $700^{\circ} \mathrm{C}$ $\mathrm{a}_{1}, \mathrm{a}_{2} \rightarrow$ Alloy 975
$\mathrm{~b}_{1}, \mathrm{~b}_{2} \rightarrow$ Alloy 976
$\mathrm{c}_{1}, \mathrm{c}_{2} \rightarrow$ Alloy $976 \mathrm{M}$ 

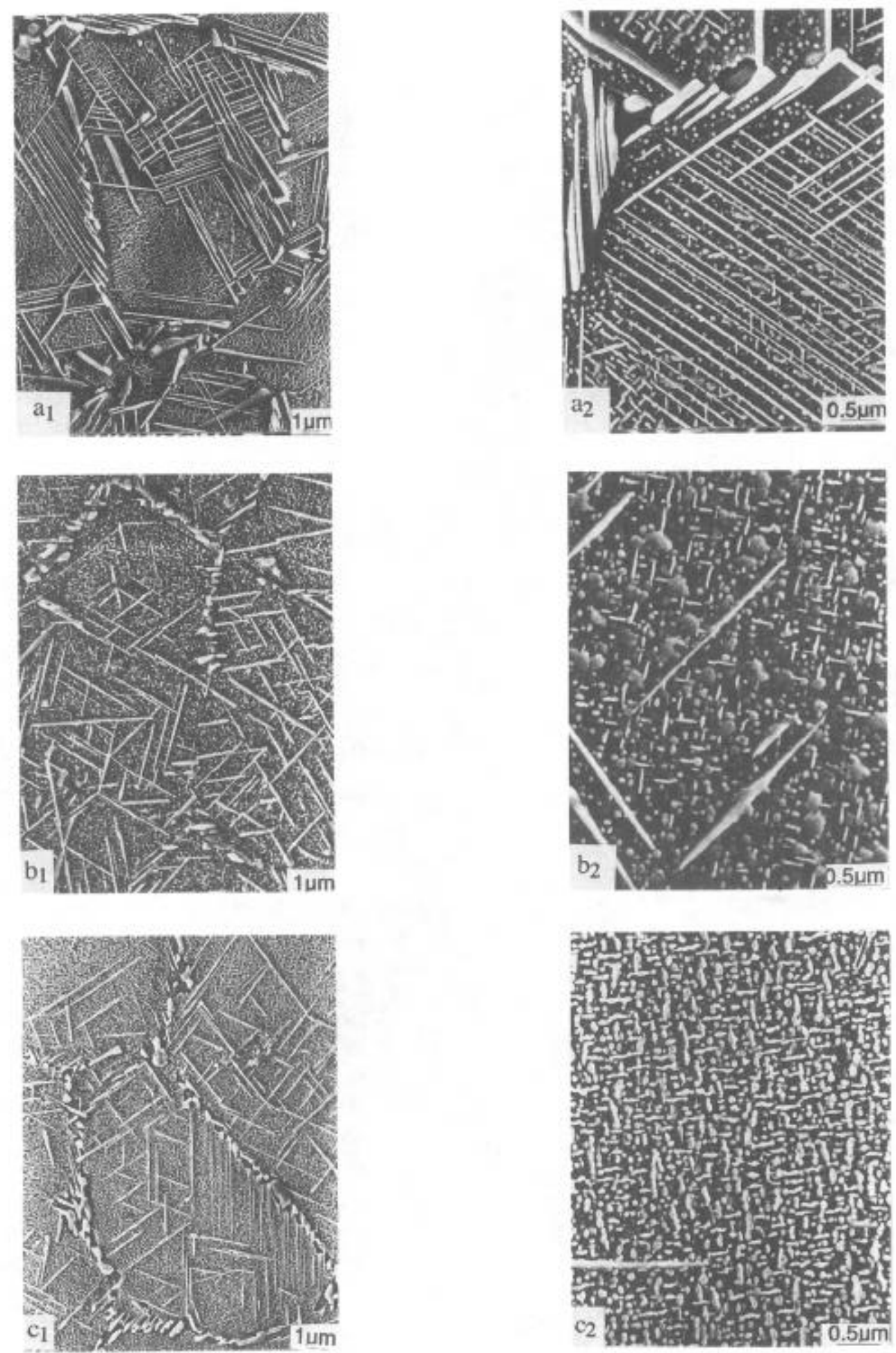

Figure 6 - SEM micrographs showing the microstructural evolutions after $10^{4}$ hours at $700^{\circ} \mathrm{C}$

$$
\begin{aligned}
& \mathrm{a}_{1}, \mathrm{a}_{2} \rightarrow \text { Alloy } 975 \\
& \mathrm{~b}_{1}, \mathrm{~b}_{2} \rightarrow \text { Alloy } 976 \\
& \mathrm{c}_{1}, \mathrm{c}_{2} \rightarrow \text { Alloy } 976 \mathrm{M}
\end{aligned}
$$



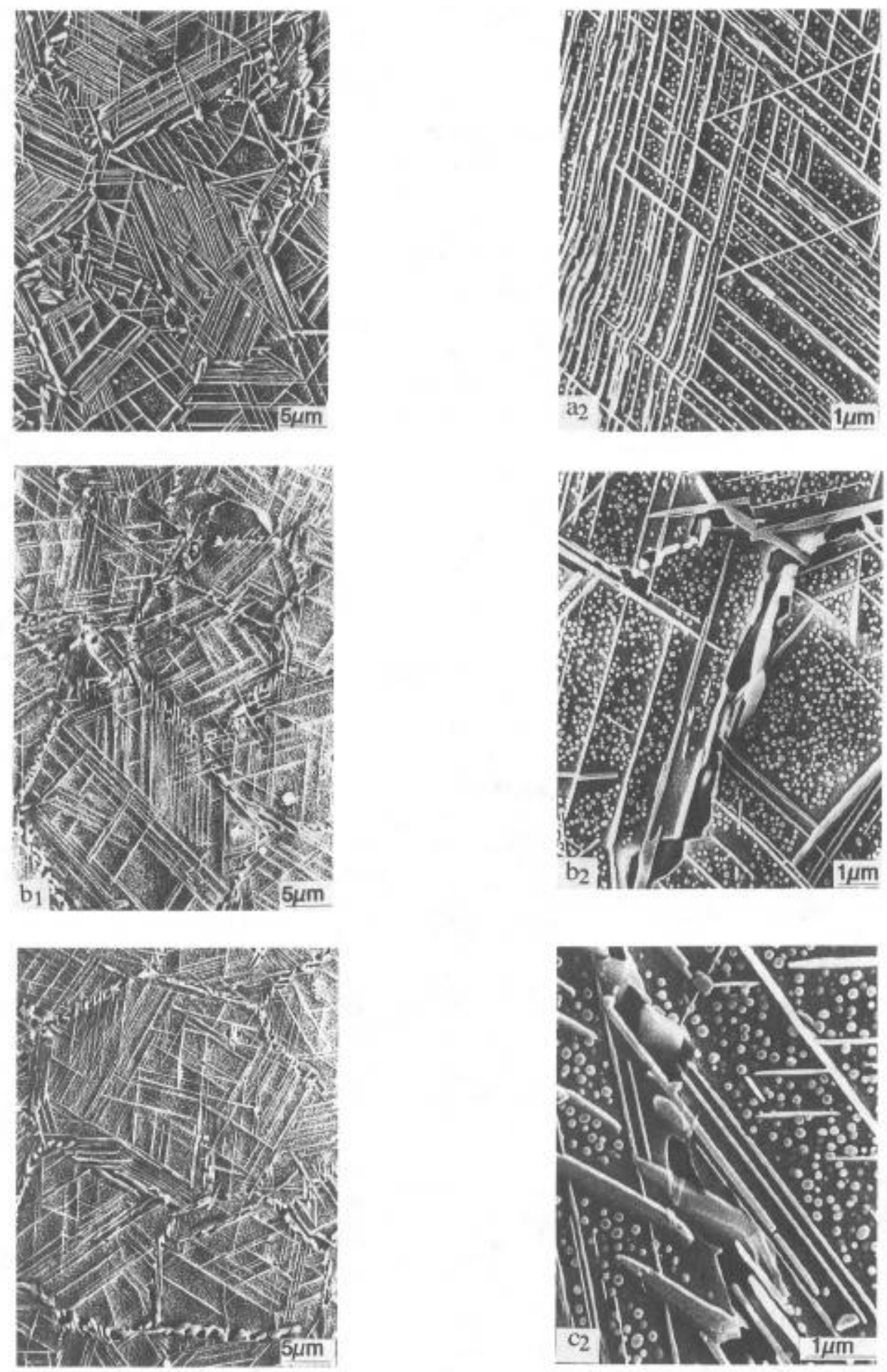

Figure 7 - SEM micrographs showing the microstructural evolutions after $10^{4}$ hours at $750^{\circ} \mathrm{C}$

$$
\begin{aligned}
& \mathrm{a}_{1}, \mathrm{a}_{2} \rightarrow \text { Alloy } 975 \\
& \mathrm{~b}_{1}, \mathrm{~b}_{2} \rightarrow \text { Alloy } 976 \\
& \mathrm{c}_{1}, \mathrm{c}_{2} \rightarrow \text { Alloy } 976 \mathrm{M}
\end{aligned}
$$


A quantitative approach of the microstructural modifications has been performed. Image analysis and manual measurements were made on TEM and SEM micrographs. The diameter of $\gamma^{\prime \prime}$ discs has been measured in nearly all the cases. The results are reported in Fig. 8.

First of all, at $650^{\circ} \mathrm{C}$ it is noticeable that the size of $\gamma^{\prime \prime}$ in Alloy $976 \mathrm{M}$ remains stable. This stability is in good agreement with hardness measurements (Fig.3). For Alloy 976, the size of $\gamma^{\prime \prime}$ particles increases rapidly and reaches an average value close to those measured in Alloy $976 \mathrm{M}$. For this alloy a comparison can also be drawn between hardness measurement and $\gamma^{\prime \prime}$ size variation.

At $700^{\circ} \mathrm{C}$, the size of $\gamma^{\prime \prime}$ precipitates in Alloy $976 \mathrm{M}$ doesn't increase initially during a thousand of hours. Then beyond this delay, the kinetics of growth of these particles are identical to those of Alloy 976. This behaviour corresponds to a progressive destruction of the compact morphology after several hundreds of hours. At $750^{\circ} \mathrm{C}$, the three alloys follow the same trend.

After aging durations larger than a few hundreds of hours, the average length of $\gamma^{\prime \prime}$ increases with time approximately as $\mathrm{t}^{1 / 3}$. These results apply essentially to isolated $\gamma^{\prime \prime}$ particles since it has been observed that associated precipitation of $\gamma^{\prime}$ and $\gamma^{\prime}$ reduces the coarsening rate (3-7).

These observations show that the main advantage of the compact morphology microstructure is to delay the coarsening process, a few thousands of hours at $650^{\circ} \mathrm{C}$ and about a thousand of hours at $700^{\circ} \mathrm{C}$.

Another consequence of the compositional modifications is to limit the volume fraction of $\delta$ phase by increasing the ratio $(\mathrm{Ti}+\mathrm{Al} / \mathrm{Nb})$. This effect is quantitatively illustrated in Fig. 9 which represents the evolution of the volume fraction of $\delta$ phase as a function of time in the three alloys, aged at $750^{\circ} \mathrm{C}$. In all cases, the $\delta$ phase content of Alloy 976, is lower than that of Alloy 975 (conventional 718). This is the reason why, modified alloys are less sensitive to averaging process. These results are consistent with those published by others investigators (5-8).

\section{Creep resistance and microstructural stability}

In this part of the work, four alloys were studied. (Alloys 975 - 976 - 976M and a conventional wrought 718 Alloy which is referred later as GIS 718). The creep behaviour of the latter has been extensively studied at $650^{\circ} \mathrm{C}$ in an earlier work [9].

Creep resistance. Testing conditions and rcsults are summarised in Table 5. It is worth noting that the minimum creep rates of powder metallurgy alloys, are lower than those measured for the wrought alloy. As the grain sizes of all the studicd alloys are similar, this difference cannot be explained by a grain size effect. It seems more reasonable to attribute this difference to the initial $\delta$ phase content of the materials which is more important in the case of the wrought alloy. The effect of intergranular $\delta$ phase precipitation on the grain boundary creep contribution in the overall creep behaviour has been studied by CHEN et al. [10]. These authors suggested that when $\delta$ phase precipitated along the grain boundaries, the creep rate is determined by the deformation of grain boundaries.

For the chosen creep testing conditions, powder metallurgy alloys behave similarly so that an effect of the compact morpholngy on creep rate has not yet been shown.

Times to fracture are equivalent for the three powder Metallurgy alloys. At $750^{\circ} \mathrm{C}$ under an applied stress of $200 \mathrm{MPa}$, the creep resistance of alloys $(975,976,976 \mathrm{M})$ is better than that the wrought alloy. Unfortunately, the poor ductility of the modified alloys is the limiting factor to their creep resistance. The failure mode of these materials was intergranular. This strongly suggests that their relatively poor ductility is related to a low gain boundary strength. It should be kept in mind that these powder metallurgy alloys were prepared from small ingots $(40 \mathrm{Kg})$ which were not given the VIM-VAR processing route 

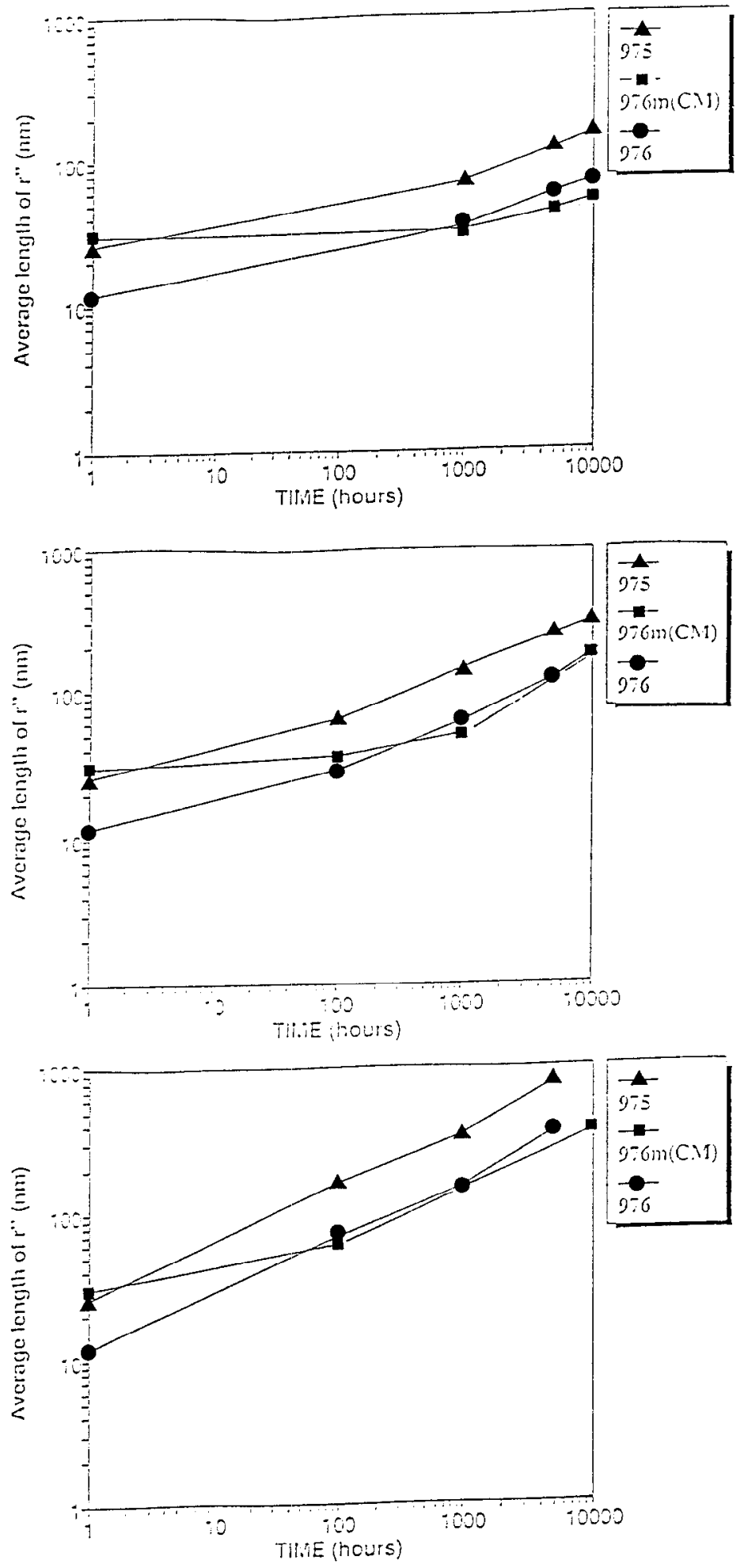

Figure 8 - Variation of the average length of $\gamma^{\prime \prime}$ precipitates as a function of time at three temperatures. $\left(650^{\circ} \mathrm{C}, 700^{\circ} \mathrm{C}, 750^{\circ} \mathrm{C}\right)$ for Alloys $(975,976,976 \mathrm{M})$. 


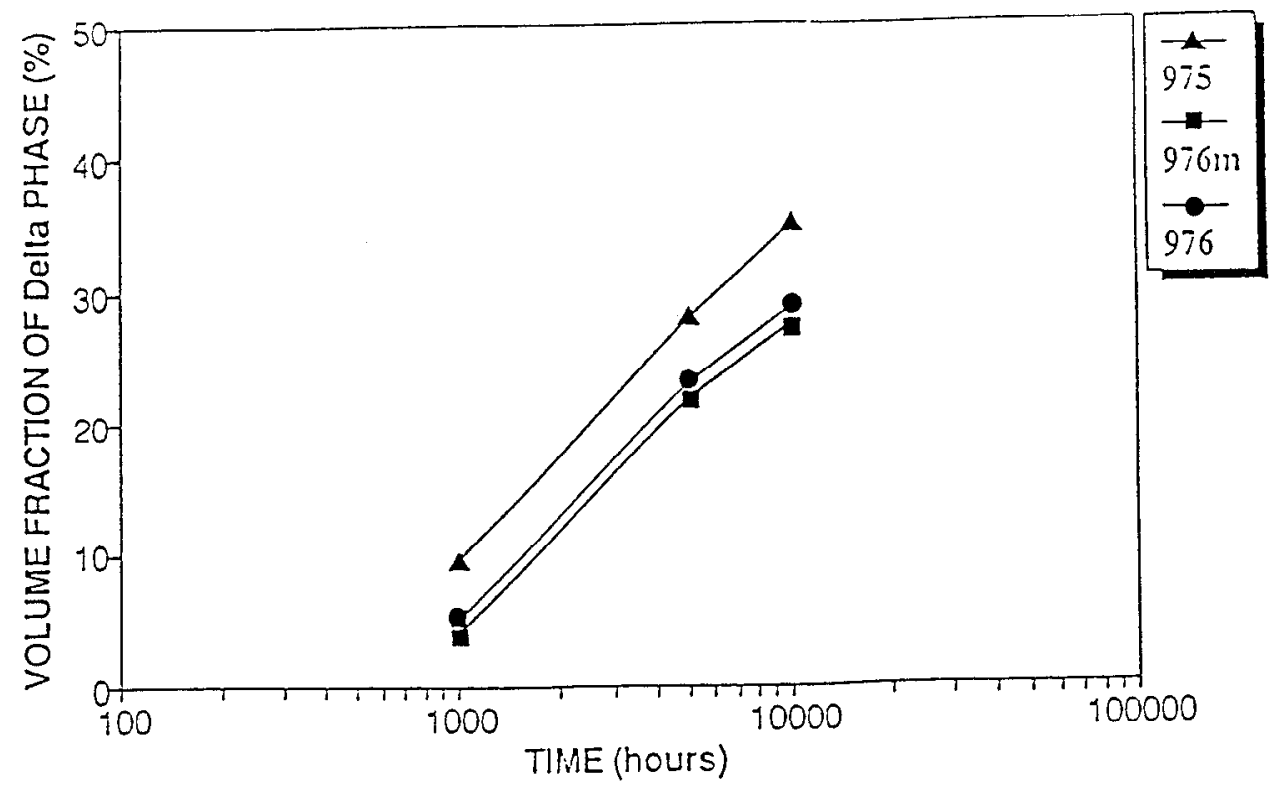

Figure 9 - Evolution of the volume fraction of $\delta$ phase as a function of aging time at $750^{\circ} \mathrm{C}$.

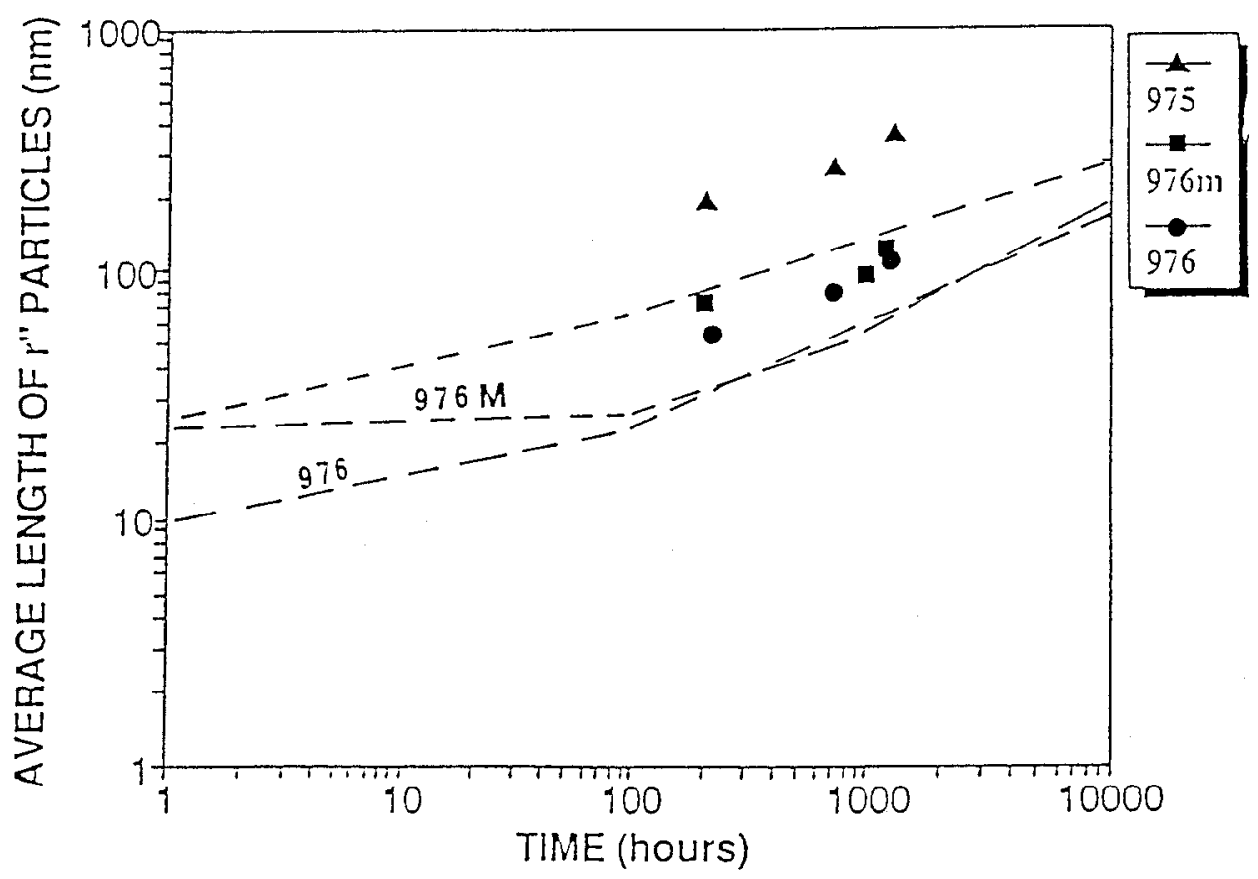

Figure 10 - Evolution of the $\gamma^{\prime \prime}$ average length during creep tests at $700^{\circ} \mathrm{C}$. (Dashed lines represent the evolution under stress free conditions). 


\section{Microstructural stability under creep conditions}

During creep all these alloys are not stable and $\delta$ phase precipitates very soon. The number of creep tests is not sufficient to conclude about the effect of an applied stress on $\delta$ phase precipitation. However, for $\gamma^{\prime \prime}$ particles the effect of an applied stress on the average length of the precipitates is presented in figure 10. The kinetic of growth is larger in Alloy 975 than in Alloys 976 and $976 \mathrm{M}$. This phenomenon has to be related to compositional modifications and can be put in parallel with the hardness evolution. Stress assisted coarsening and dissolution of $\gamma^{\prime \prime}$ precipitates have already been evidenced in Alloy $718(5,11)$.

Table 5 - Creep testing conditions and results.

\begin{tabular}{lllll}
\hline & & $\mathrm{t}_{\mathrm{R}}(\mathrm{h})$ & $\dot{\varepsilon}_{\min } \times 10^{-6}\left(\mathrm{~h}^{-1}\right)$ & $\varepsilon_{\mathrm{R}}(\%)$ \\
\hline $700^{\circ} \mathrm{C}-350 \mathrm{MPa}$ & 975 & 1250 & 4.0 & 5.6 \\
& 976 & 1218 & 4.5 & 8.6 \\
& $976 \mathrm{M}$ & 1200 & 4.8 & 6.0 \\
\hline & 975 & 721 & 7.1 & 5.0 \\
& 976 & 710 & 8.6 & 6.3 \\
$700^{\circ} \mathrm{C}-400 \mathrm{MPa}$ & $976 \mathrm{M}$ & 999 & 7.7 & 5.9 \\
& GIS 718 & 460 & 70.0 & 38.0 \\
\hline \multirow{3}{*}{$700^{\circ} \mathrm{C}-500 \mathrm{MPa}$} & 976 & 210 & 35.0 & 9.8 \\
& 975 & 223 & 36.0 & 9.7 \\
& $976 \mathrm{M}$ & 202 & 45.0 & 8.1 \\
\hline & 975 & 800 & 9.3 & 7.0 \\
& 976 & 760 & 10.0 & 6.0 \\
$750^{\circ} \mathrm{C}-200 \mathrm{MPa}$ & $976 \mathrm{M}$ & 768 & 9.5 & 8.3 \\
& GIS718 & 350 & 104.0 & 34.0 \\
\hline
\end{tabular}

\section{Conclusions}

1. Minor chemical composition modifications of Alloy 718 can favor the $\gamma$ precipitation and hence promote an associated precipitation of $\gamma^{\prime \prime}$ to lead to a compact morphology microstructure. This microstructure has been obtained in fine grain alloy containing very few $\delta$ phase particles.

2. Modificd alloys are more resistant to overaging phenomenon than Alloy 718 even for aging times up to 10000 hours at temperatures of $650^{\circ} \mathrm{C}, 700^{\circ} \mathrm{C}, 750^{\circ} \mathrm{C}$.

3. The origin of the improvement of the thermal stability is two-fold:

It is due at first to the better thermal stability of $\gamma^{\prime}$ precipitates in comparison with $\gamma^{\prime \prime}$ platelets. The second origin of this significant improvement lies in the associated precipitation of the $\gamma^{\prime}$ and $\gamma^{\prime \prime}$ phases which decreases the growth kinetic of $\gamma^{\prime \prime}$.

4. Tensile properties of the studicd alloys are comparable to those of conventional Alloy 718.

$\underline{5}$. The creep resistance at high temperature $\left(700^{\circ} \mathrm{C}-750^{\circ} \mathrm{C}\right)$ of the different heats $(975,976$, $976 \mathrm{M}$ ) is better than that of wrought alloy 718 . Nevertheless, the ductility of these P.M. alloys is too low. 


\section{Acknowledgments}

The authors would like to Acknowledge financial support from SNECMA and many fruitful discussions in particular with Dr Y. Honnorat and Dr J.Y. Guedou from this company.

\section{$\underline{\text { References }}$}

1. J.W. Brooks and P.J. Bridges, Metallurgical Stability of Inconel Alloy 718, (Superalloys, 1988), 33 .

2. J. Radavich, A Current TTT Diagram for Wrought Alloy 718. (Superalloys 718, 625, 1991), 325 .

3. R. Cozar and A. Pineau, Morphology of $\gamma^{\prime}$ and $\gamma^{\prime \prime}$ Precipitates and Thermal Stability of Inconel 718 Type Alloys, (Metall. Trans., vol.4, 1973), 47.

4. E. Andrieu, R. Cozar and A. Pineau, Effect of Environment and Microstructure on the high l'emperature Behaviour of Alloy 718. (Superalloy 718, 1989), 241.

5. E. Guo, G. Xu and E.A. Loria, Effect of Heat Treatment and Compositional Modification on Strengthening and Thermal Stability of Alloy 718 (Superalloys 718, 625, 1989), 389-408.

6. J.P. Collier, A.O. Selius and J.K. Tien, On Developing a Microstructurally and Thermally Stable Iron-Nickel Base Superalloy, (Superalloys 1988), 43.

7. J.P. Collier, S.H. Wong, J.C. Phillips and J.K. Tien, The Effect of Varying Al, Ti and Nb Content on the Phase Stability of Inconel 718, (Met. Trans. A, vol.12A, 1988), 1657.

8. J.A. Manriquez, P.L. Bretz, L. Rabenberg and J.K. Tien, The High Temperature Stability of In 718 Derivatives Alloys, (Superalloys 1990), 507-516.

9. R. Molins, E. Andrieu and A. Pineau, Overaging Deformation and Rupture Micromechanisms of Alloy 718 in Relation to Notch Creep Rupture Strength, (Superalloys 718, 625, 1991) 589602 .

10. W. Chen and M.C. Chaturvedi, Grain Boundary Dependent Creep Behaviour of Inconel 718 , (Can Met. Quat., 32, 1993), 363-367.

11. J. Oblak, D. F. Paulonis and D.S. Duvall, Coherency Strengthening in Ni Base Alloys Hardened by $\mathrm{DO}_{22} \gamma^{\prime \prime}$ precipitates, (Met. Trans., 5, 1974), 143-153. 